\title{
Complementary Therapies in Breast Cancer Patients
}

\author{
Axel Eustachi \\ Zentrum für naturheilkundliche Forschung, II. Med. Klinik und Poliklinik der TUM, Klinikum rechts der Isar, München, Germany
}

\section{Key Words}

Breast cancer · Complementary therapies · Nutrition · Homeopathy · Herbal therapies · Traditional Chinese medicine

\section{Summary}

The use of complementary therapies in addition to standard care for cancer is widespread among cancer patients, but it seems to be of special importance for women with breast cancer. There is a large number of nonconventional therapies, and only very few can be judged on a sound scientific basis. Nevertheless, information on the safety profiles and scientific evidence are increasing for some of these treatments. This article focuses on treatments which are of special interest for breast cancer patients because they might reduce typical symptoms of breast cancer and side effects of conventional cancer therapy like fatigue, anxiety, menopausal symptoms, nausea, lymphedema, and dermatitis. Many of the therapies described can be used as self-help techniques. If standard cancer therapy is not able to sufficiently control symptoms or adverse effects, some complementary treatments might offer further options for the maintenance of a good quality of life for cancer patients. Breast cancer patients tend to be more active in seeking information about complementary methods than other cancer patients. Practitioners should respond to this need and discuss nonconventional therapies with their patients in an objective way.

\author{
Schlüsselwörter \\ Brustkrebs · Komplementäre Therapien · Ernährung · \\ Homöopathie · Kräutertherapie · Traditionelle \\ chinesische Medizin
}

\section{Zusammenfassung}

Die Anwendung komplementärer Therapien als Ergänzung zur Standardbehandlung bei Krebs ist weit verbreitet bei Krebspatienten, sie scheint jedoch für Brustkrebspatientinnen von besonderer Bedeutung zu sein. Es existiert eine große Vielfalt unkonventioneller Therapien, und nur sehr wenige können derzeit auf einer soliden wissenschaftlichen Grundlage bewertet werden. Dennoch vermehrt sich sowohl das Wissen über die Sicherheitsprofile als auch die wissenschaftliche Evidenz für einige dieser Therapiemethoden ständig. Dieser Artikel beschreibt Behandlungen, die von besonderer Bedeutung für Brustkrebspatientinnen sind, da sie typische Symptome der Brustkrebserkrankung und Nebenwirkungen der konventionellen Krebsbehandlung vermindern können, wie Fatigue, Angst, klimakterische Beschwerden, Übelkeit, Lymphödeme und Dermatitis. Viele der beschriebenen Therapien können als Selbsthilfetechniken angewendet werden. Wenn die Standardbehandlung bei Krebs die Krankheitssymptome oder Nebenwirkungen nicht ausreichend kontrollieren kann, stellen einige komplementäre Therapiemethoden eine zusätzliche Option zur Erhaltung der Lebensqualität der Krebspatienten dar. Brustkrebspatientinnen suchen aktiver als andere Krebskranke nach Informationen über komplementäre Therapiemöglichkeiten. Ärztinnen und Ärzte sollten auf dieses Bedürfnis eingehen und unkonventionelle Methoden objektiv mit ihren Patientinnen besprechen.

\begin{tabular}{ll}
\hline KARGER & @ 2007 S. Karger GmbH, Freiburg \\
Fax +497614520714 & Accessible online at: \\
$\begin{array}{l}\text { E-mail Information@Karger.de } \\
\text { www.karger.com }\end{array}$ & www.karger.com/brc \\
&
\end{tabular}

Dr. Axel Eustachi

Arzt für Naturheilverfahren, Zentrum für naturheilkundliche Forschung (ZNF),

II. Med. Klinik und Poliklinik der TUM, Klinikum rechts der Isar

Kaiserstr. 9, 80801 München, Germany

Tel. +49 89726 697-0, Fax -21

E-mail ZnF@lrz.tu-muenchen.de 


\section{Introduction}

A significantly increasing number of breast cancer patients take advantage of so-called nonconventional methods, in addition to the classical therapeutic strategies. Recent surveys indicate that between 48 and $83 \%$ of breast cancer patients turn to complementary therapies, with an upward trend in the past 10 years $[1,2]$. The wide range of the methods used can be explained by differences in the definition of complementary methods, in the sociocultural background of patients, and in the size of the populations included in these studies [2]. The most frequently used methods include herbal medicines, medicinal teas, dietary supplements, mind-body approaches (i.e. relaxation techniques, spiritual therapies), homeopathy, vitamins/minerals supplementation, and acupuncture [2, 3].

The definition 'complementary and alternative medicine' (CAM) refers to the complementation of conventional medicine by nonconventional methods. These methods do not necessarily derive from classical (European) naturopathy (light-, air-, water-based therapies, physiotherapy, nutrition, phytotherapy), but may be part of other therapeutic systems (e.g. traditional Chinese medicine, acupuncture) or they may have a completely different conceptual basis (e.g. homeopathy). The emphasis should clearly be put on the definition 'complementary', as nonconventional methods should sensibly support and complement conventional methods and should not, as a rule, be considered as an alternative to them.

The majority of the studies on complementary methods in breast cancer patients have been performed in the US. American patients seem to prefer different nonconventional methods compared with European patients: for example, homeopathy is more frequently applied in Europe $[4,5]$. The majority of the studies, however, agree on the fact that breast cancer patients take advantage of nonconventional therapeutic methods in a significantly higher number than other cancer patients $[6,7]$.

Complementary therapies are taken into consideration with higher frequency by women who have a higher education level, belong to a higher socioeconomic status, and are younger than patients who do not consider the use of CAM [8].

Several reasons can be found to explain the request of breast cancer patients for complementary therapeutic methods. First, their tendency to look for holistic approaches and their belief that a more 'natural' and therefore a softer or less dangerous treatment may counter the drawbacks of conventional diagnostic and therapeutic approaches, that are often perceived as aggressive and threatening. Second, the need for boosting the immune system and for engaging actively in improving the sense of well-being and regaining control on their quality of life [9]. Patients who experience a diminished quality of life due to the toxicities caused by chemo- and radiotherapy that cannot be satisfactorily controlled with conventional methods understandably look for alternative possibilities of treatment. Patients who use nonconventional therapeutic methods often report an improved physiologic and psychosocial well-being already during chemo- and radiotherapy treatments [10]. The clinical experience shows that, after termination of the primary therapy, the motivation of the patients for using complementary methods changes and the aim with which they approached complementary methods shifts the targets that are being sought. The simple amelioration of the symptoms and improvement of quality of life is substituted by the wish to prevent tumor recurrence [11]. The use of complementary methods appears to fulfill an important psychological need of breast cancer patients in response to a reduced quality of life and the psychosocial distress caused first by the cancer diagnosis and then by the side effects of conventional treatment $[5,9]$.

The most common source of information for breast cancer patients about nonconventional methods are other patients, self-help groups, friends, family, and the mass media. This means that patients can often hardly discriminate between scientifically correct information and information that is influenced by advertisement and commercial interests. The number of patients who consult their physician with questions on complementary treatment methods is worryingly low: in a recent European study the rate of patients gaining information through their physicians was $17.9 \%$ (which was the highest rate reported ever in this field) [2]. The reasons for this phenomenon seem to lie in the often categorical rejection of many physicians of nonconventional methods and in the concern of patients to harm the relationship with their physician through unwanted questions.

Due to the increasing interest in nonconventional therapies, crucial questions that are important for both patients and physicians must be asked: 1 . Which methods are evidencebased? 2. Which methods can possibly be recommended based on clinical and practical experience and have been proven safe? 3. Which methods are not suitable to be applied or are even dangerous?

This article will focus on complementary therapeutic methods that can be recommended to breast cancer patients because they base themselves on a certain degree of evidence and show an acceptable safety profile. The methods herein described are those that are most frequently selected by European breast cancer patients to complement conventional antitumor therapies (table 1).

\section{Moderate Physical Activity - the Basic Recommendation for All Breast Cancer Patients}

Regular but moderate physical activity must be recommended to the majority of breast cancer patients with no contraindications, based on scientific evidence and on the ease of performance. $3-5 \mathrm{~h} /$ week of moderate physical exercise with an intensity of $50-75 \%$ of age-adjusted maximum heart rate seem to be of functional as well as of psychological benefit already 
Table 1. Symptoms of breast cancer patients and complementary therapies

\begin{tabular}{lll}
\hline Symptom & $\begin{array}{l}\text { Therapies with acceptable scientific } \\
\text { evidence and acceptable safety profile }\end{array}$ & Therapies with potential benefit \\
\hline $\begin{array}{l}\text { Fatigue } \\
\begin{array}{l}\text { Anxiety } \\
\text { Nausea/vomiting }\end{array}\end{array}$ & $\begin{array}{l}\text { physical exercise } \\
\text { mind-body therapies } \\
\text { acupressure, acupuncture } \\
\text { vasomotor symptoms } \\
\begin{array}{l}\text { Lymphedema } \\
\text { Dermatitis } \\
\text { (radiotherapy-induced) }\end{array}\end{array}$ & $\begin{array}{l}\text { massage therapy, acupuncture, carnitine, ginseng } \\
\text { physical exercise } \\
\text { massage therapy, ginger } \\
\text { acupuncture, vitamin E, homeopathy, black cohosh }\end{array}$ \\
\hline
\end{tabular}

during a chemotherapy regimen $[12,13]$ and to correlate positively with a better survival in breast cancer patients [14].

Possible dangers of physical exercise are the worsening of lymph edemas or shoulder tendonitis, as well as cardiac overload of the patients. All of these potential dangers can be minimized by determining the individual physical performance and modifying the recommendations, as well as by a proper information and education of the patients on a case-to-case basis.

\section{Fatigue}

The most valuable treatment against fatigue, for the effectiveness of which a certain degree of scientific evidence has been gained, is the performance of regular moderate physical exercise [12]. Fatigue affects almost all cancer patients and is defined 'as persistent, subjective sense of tiredness related to cancer or cancer treatments that interferes with usual functioning' [15]. Fatigue can be described as a reduced functioning that affects a person's body and mind and has an impact on capacity at physical, mental, emotional, and social levels. It can be triggered by chemo- and radiotherapy and affects acutely $60-90 \%$ of all cancer patients. Particularly problematic is the fact that, in the long term, at least $30 \%$ of patients receiving radiotherapy suffer from fatigue. This means that, at the end of a conventional therapy regimen, a return to normal functionality and daily life is not possible for many patients, with all the consequences that this may have for their quality of life $[16,17]$.

Further treatment options that may be of significance but on whose usefulness no sufficient evidence has yet been gathered are acupuncture ([18]; see chapter 'Acupressure, Acupuncture') and the administration of carnitine [19].

\section{Quality of Life}

The presently available studies indicate that a moderate exercise program can improve the overall quality of life in breast cancer patients. The positive effects of exercise are, however, experienced with a delay and only if regular performance of the physical exercise is maintained $[13,20]$. There is limited evidence from one trial that physical exercise may reduce anxiety. Effects on mood disturbances, depression, and immune function have not been scientifically proven in accurate trials [12].

\section{Mind-Body Therapies}

The most recent literature, under the definition 'mind-body therapies', includes a series of individual techniques such as relaxation, guided imagery, cognitive therapy, hypnosis, and behavioral therapy. The aim of all of these therapies is to enhance quality of life during and after conventional cancer treatment. One meta-analysis [59] has demonstrated the potential positive effect of mind-body therapies on the quality of life of cancer patients leading to control of mood disturbances, anxiety, and depression.

Some authors point out that relaxation is a very cost-effective technique to reduce anxiety, distress, tension, depression, anger, and fatigue (e.g. in radiation therapy patients), that lacks any side effects. Also nausea associated with chemotherapy might be lessened to some extent by relaxation [9]. The choice of single relaxation techniques should be based mainly on scientific evidence and their suitability for the efficient treatment of the symptoms.

All in all, mind-body therapies can be recommended to all cancer patients as a complement to conventional treatments, as they are based on sufficient evidence, do not pose safety problems, and are available to a great number of individuals. They require a certain degree of instruction of the patients through specialized health personnel, but in the long term they can be autonomously performed by the patients without attending therapeutic sessions.

\section{Massage Therapy}

This term includes a variety of different techniques (i.e. manual lymphatic drainage, classical massage, reflexology, shiatsu, Reiki, Rolfing, deep tissue massage), all of which aim to reduce pain and tension and to improve blood flow and relaxation in muscle or connective tissues.

\section{Application for Lymphedema}

Manual lymphatic drainage should be recommended as a standard therapy for breast cancer patients to reduce excess limb volume especially after lymphonodectomy and to improve quality of life [21]. This acquires even greater importance 
Table 2. Levels of evidence (LOE) and grades of recommendation (GR) for nutrition after breast cancer diagnosis (in: AGO Guidelines for Breast Cancer: Complementary Therapies; www.ago-online.org)

\begin{tabular}{lll}
\hline & LOE $^{\mathrm{a}}$ & $\mathrm{GR}$ \\
\hline Avoidance of overweight in & & \\
$\quad$ postmenopause & $1 \mathrm{~b}$ & $\mathrm{~B}$ \\
Low-fat diet & $2 \mathrm{~b}$ & $\mathrm{~B}$ \\
Fruits and vegetables & $3 \mathrm{a}$ & $\mathrm{B}$ \\
Whole grain & 4 & $\mathrm{C}$ \\
\hline
\end{tabular}

a Oxford Centre for Evidence-Based Medicine Levels of Evidence (May 2001).

when breast cancer patients start an exercise program, as it may prevent possible negative effects that may be linked to the physical exercise itself.

\section{Application for Other Symptoms}

There is evidence that several types of massage can reduce not only anxiety and pain, but also fatigue, distress, and nausea. Whether this improvement in quality of life has a bearing on the enhancement of the immune system in breast cancer patients remains unclear. There are some data supporting this hypothesis, such as an increase in natural killer cell and lymphocyte counts after massage and relaxation therapy for 30 minutes, three times a week over five weeks $[22,23]$.

All of these methods should be performed by professional therapists who are aware of the patients' individual diagnoses and of possible risks each patient may encounter (i.e. fracture risk because of bone metastases, tissue lesions during/after radiation).

\section{Nutrition}

\section{Reduced Fat Intake}

In postmenopausal breast cancer patients, a reduction of dietary fat intake and an increased intake of fruits and vegetables may lead to a reduction in the risk of disease recurrence (table 2). Especially patients with an initial high-fat diet seem to profit from a switch to a reduced fat intake [24]. It remains to be clarified in further studies which specific fats should be reduced or avoided and whether/how they relate to the receptor status of the tumor.

A diet rich in fruits, vegetables, and whole grain, containing high amounts of mono- and polyunsaturated fats belongs presently to the sensible primary and secondary prevention of a whole series of chronic conditions. As at present there is no indication that such a diet can be harmful to breast cancer patients, it should be recommended in view of a long-term prevention program $[25,26]$.

\section{Soy Products}

Soybean isoflavones (e.g. genistein, daidzein, glycitein) are considered selective estrogen receptor modulators. Extracts of soybeans are used by postmenopausal women to lessen the symptoms of reduced levels of estrogen. A high dietary intake of soy products caused a significant proliferation of normal breast lobular epithelium, whereas other studies performed on pre- and postmenopausal women showed no effect on the thickness of the breast gland tissue by a diet rich in soy-based products [27].

In vitro experiments showed that the stimulation of breast cancer cells is possible through soy isoflavones. This observation led to the belief that soy and soy products could possibly stimulate growth of cancer cells in receptor-positive breast tumors. This hypothesis has not been confirmed so far in breast cancer patients.

A recent review [28] comes to the conclusion that no final statement is presently possible on whether the intake of soy-based products may constitute a risk for breast cancer patients. Although there is no clear indication that the occasional intake of soy-based products leads to a growth stimulation of breast tumor cells, at least for the time being, the regular intake of soy-based products and the long-term intake of soy extracts (e.g. for decreasing menopausal symptoms upon antihormonal therapy) by breast cancer patients is not to be advised.

\section{Nutritional Approaches for Hot Flashes}

To control the symptoms of estrogen withdrawal, patients should be advised to avoid spicy foods, hot drinks, hot foods, and alcohol. Instead they should increase the daily amounts of cold fluids (water, tea) to about 2 1/day and consume herbs and fruits with reported cooling effects (i.e. green tea, peppermint, lemon). Further possible approaches include behavioral strategies like wearing light clothes and lowering room temperature [29].

\section{Acupressure, Acupuncture}

\section{Nausea and Vomiting}

Acupressure und acupuncture can be used for relief of nausea and vomiting based on information derived from clinical trials $[30,31]$. Acupressure through manual stimulation in the wrist or through wristbands is a self-help technique with a good safety profile that is available to every patient in case of nausea [32]. In contrast, needle acupuncture is an invasive method that must be performed by specialized personnel and that should not be used in case of thrombocytopenia, coagulopathy, and neutropenia [19].

\section{Pain}

Acupuncture and auricular acupuncture are scientifically proven methods to reduce pain. As an addition to convention- 
al analgesic therapy for cancer pain or in a palliative care situation it is reasonable to try acupuncture as a treatment option. Thus, it may be possible to offer additional pain management to patients with side effects of conventional therapy or with insufficient pain relief due to their disease state [33].

\section{Fatigue}

Acupuncture is possibly a meaningful complement to physical exercise in the handling of fatigue. The choice of acupuncture points should be made on the basis of the individual diagnosis and should be implemented after careful consideration of other methods that may be better suited for the purpose [34, 35].

\section{Hot Flashes}

There is very limited evidence from clinical trials that acupuncture may reduce hot flashes caused by estrogen ablation [36]. It is, however, known that the placebo effect in the treatment of hot flashes is substantial. Whether acupuncture is advisable for this complication should be established on a case-to-case basis.

\section{Vitamin and Trace Element Supplements}

The intake of complex dietary supplements during chemo- or radiotherapy is not advised for patients with a normal and complete diet. There is at present no scientific indication that the intake of dietary supplements may protect from disease recurrence or that it may prolong life expectancy in patients with a normal food intake [37]. Care should, however, be taken in each individual case that a sufficient supply of vitamins and trace elements is provided.

\section{Increased Loss of Vitamins and Trace Elements under Chemotherapy}

There is at the moment limited evidence speaking in favor of the intake of specific vitamins and trace elements that, however, does not justify a general recommendation. Two aspects of cisplatin therapy that may speak for supplementation are mentioned as exemplary: i) upon therapy with this compound there may be an increased urinary loss of magnesium [38]; ii) there are suggestions that the neurotoxicity of cisplatin might be decreased by vitamin E [39]. It is advisable to consider the need of additional supply of vitamins and trace elements based on the toxicity of the conventional therapy applied and on the overall nutritional situation of the patient.

\section{Vitamin E for Hot Flashes}

There is limited evidence for the use of vitamin E (800 IU/ day) to reduce hot flashes in breast cancer patients, but it is unclear whether and to what extent this might be due to a placebo effect. Although no toxic effects have been reported so far with $800 \mathrm{IU} /$ day, the existing data are not sufficient to recommend vitamin $\mathrm{E}$ for all cancer patients [40].

\section{Carnitine for Fatigue}

The administration of L-carnitine in order to reduce fatigue seems to be a safe treatment option in patients for whom other therapeutic interventions are not sufficiently effective [19].

\section{Homeopathy}

The use of classic homeopathy for the improvement of unwanted side effects linked to the conventional cancer therapies (i.e. estrogen withdrawal) showed positive effects in a few trials. Under rigorous scientific monitoring it is, however, still not clear whether the therapeutic effects are due to the particular setting of classic homeopathy (i.e. the extensive diagnostic/therapeutic session taking place prior to treatment) or to the homeopathic treatment itself. In addition, a potential influence of a placebo effect should be taken into account in analyzing the results obtained with homeopathy before drawing definite conclusions. The scientific evidence on homeopathy is not sufficient, and further trials are necessary. In the hands of a responsible physician, homeopathy can, however, constitute an important complementary method in single cases, in the frame of a holistic tumor therapy approach, also in view of the good safety profile and of the few studies that indicate a high degree of patient satisfaction under homeopathic treatment [41, 42].

\section{Herbal Therapies}

\section{Black Cohosh for Menopausal Symptoms}

Black cohosh (Cimicifuga racemosa L.) has been traditionally used by American Indians to treat menopausal symptoms (e.g. hot flashes, mood problems, perspiration, vaginal dryness). Although newer review articles provide good scientific evidence for the use of black cohosh to treat menopausal symptoms, it is still not clear whether this is due to a considerable placebo effect. Furthermore, knowledge about long-term (over 6 months) efficacy and safety is still lacking.

The possible mechanism of action suggests that black cohosh acts as a selective estrogen receptor modifier and might have an agonistic effect on serotonin receptors. The effect seen on estrogen receptors led to the recommendation to avoid black cohosh in breast cancer patients. It must be pointed out that negative effects for breast cancer patients have never been demonstrated by clinical data. Nevertheless, black cohosh should not be recommended as a first-line complementary treatment for menopausal symptoms, since there is good evidence for the beneficial effect of lifestyle changes (exercise) with a better safety profile [43].

\section{Calendula for Skin Protection from Radiation}

Calendula officinalis has a long tradition in European herbal therapy and is used on a merely empirical basis to treat skin lesions caused by heat or sunlight. 
In studies performed on breast cancer patients receiving radiation therapy, calendula ointment applied twice daily on the breast reduced the recurrence of severe dermatitis (skin irritation, redness, pain) [44]. Shortcomings of this study (no control group, no comparison made with conventional therapies) do not allow any general recommendation, but it seems reasonable to consider calendula ointment as a valid option, when the suffering of patients affected by radiation dermatitis cannot be sufficiently reduced with better proven therapies.

\section{Ginger for Nausea and Vomiting}

Ginger (Zingiber officinale), a medicinal plant of traditional Chinese medicine and other Asian therapeutic systems used to treat nausea, loss of appetite, and to warm the body, is increasingly utilized by patients both in Europe and the US.

There is some limited evidence from clinical trials that ginger may reduce nausea associated with chemotherapy, but results still remain contradictory. It is still unclear which dosage is effective and safe. There is a large variety of highly effective prescription drugs to control nausea in cancer patients undergoing chemotherapy. Ginger might be chosen if all of these therapeutic options do not lead to the desired effect or if they are not well tolerated by the patient. In this case, up to one gram ginger per day seems to be an acceptable dose over a period of 5-7 days. It should be noted, however, that ginger may have some interactions with other medications (e.g. blood-thinning medications) and increase stomach acid production [45-47].

\section{Ginseng for a Better Quality of Life}

Asian ginseng (Panax ginseng C.A. Meyer) and American ginseng (Panax quinquefolius L.) are two of the most popular herbal remedies to improve fitness, vitality, and longevity based on an over 2000-year-old tradition in Chinese medicine. Ginseng has been proven to have positive effects on the cardiovascular, immune, endocrine, and nervous system [48, 49]. Nevertheless, undesired side effects have been described (e.g. raised blood pressure, sleeping disorders, and phytoestrogenic effects). Therefore, it should be recommended to patients with caution.

It has been suggested that for breast cancer patients with estrogen receptor-positive tumors ginseng might represent a possibly dangerous treatment because of its estrogenic properties [50]. On the other hand, there is limited evidence from Asian studies that quality of life and even survival in ginseng users might be better than in nonusers [51]. The existing evidence does not support a negative or dangerous effect of ginseng on the prognosis of breast cancer patients, but it is advisable to try all better proven options to improve quality of life before considering the use of ginseng.

\section{Mistletoe}

The use of mistletoe as a complementary therapy for cancer is widespread in Central Europe. Over $77 \%$ of all cancer pa- tients use it, and breast cancer patients apply it more frequently than any other group of cancer patients [52]. In view of the high demand it is compulsory for physicians to be aware of this form of therapy.

The mistletoe therapy consists normally of subcutaneous injections of extracts of the plant Viscum album. Many of the available trials on mistletoe therapy have methodological weaknesses and do not allow any definite conclusions or general recommendations. Even if different antitumoral and immune-enhancing effects have been described, the positive effects on the quality of life of the patients seem to play the most important role. Based on the present status of clinical trials, a prolongation of life expectancy of breast cancer patients seems possible, but has not been definitely proven [53].

Although one research group [54] showed the growth stimulation of tumor cells by mistletoe, the results of the study could not be reproduced by other groups [55]. This study is, nevertheless, often cited by adversaries of mistletoe therapy in order to warn patients against this form of therapy.

Possible symptoms that occur more frequently during mistletoe therapy are local reactions (redness, swelling) at the injection site and fever. In certain therapy models these symptoms are taken as a positive sign indicating a reaction of the patient. Care should be, however, exercised in case of acute inflammatory diseases, as well as brain and bone marrow tumors.

General recommendations for mistletoe therapy cannot be made at present. The hints that in the adjuvant as well as palliative situation mistletoe therapy may represent a therapeutic option to improve life quality are, nevertheless, increasing. The decision in favor of a mistletoe therapy should obviously always be made after careful consideration of all better studied options for improving clinical outcomes [56].

\section{Traditional Chinese Medicine}

\section{Medicinal Herbs}

An improvement in nausea and vomiting, fatigue, and white blood cell counts has been obtained in Chinese breast cancer patients with traditional Chinese herbal prescriptions in combination with chemotherapy. Chemotherapy-induced bone marrow, liver, and kidney toxicity appeared to be lowered by complementary herbal treatment. Although promising, these studies do not allow a general recommendation, but further studies are justified [57].

\section{Qigong}

There are limited hints that performance of qigong exercises (a relaxation technique consisting of breathing, stretching, and slow moving meditative postures) already during a chemotherapeutic regimen can reduce pain, numbness, heartburn, dizziness, and symptoms of psychological distress [58]. 
Table 3. Levels of evidence (LOE) and grades of recommendation (GR) for complementary treatment options (in: AGO Guidelines for Breast Cancer: Complementary Therapies; www.ago-online.org)

\begin{tabular}{lll}
\hline & LOE $^{1}$ & GR \\
\hline Sports/gymnastics & $3 \mathrm{a}$ & $\mathrm{C}$ \\
Mistletoe & 4 & $\mathrm{D}$ \\
Soy & 5 & $\mathrm{D}$ \\
High-dose vitamins & $3 \mathrm{~b}$ & $\mathrm{C}$ \\
Orthomolecular substances & 5 & $\mathrm{D}$ \\
\hline
\end{tabular}

${ }^{1}$ Oxford Centre for Evidence-Based Medicine Levels of Evidence (May 2001).

\section{Conclusion}

Complementary therapies are able to manage symptoms that worsen a breast cancer patient's quality of life: fatigue, pain, nausea, anxiety, and hot flashes can be treated by several nonconventional therapies without affecting the efficacy of the standard therapy (table 3).

Health care professionals should be aware of the fact that information about and the use of nonconventional therapies is of great importance for breast cancer patients. On the basis of current scientific evidence it is no longer acceptable that this topic is disregarded by physicians, thus preventing their patients from getting objective information on complementary therapies. It has to be expected (and hoped) that physicians and nursing staff will be more often confronted with questions about complementary therapeutic methods in the near future. These questions should lead to a comprehensive and serious counseling of patients by health care personnel on advantages and limitations of complementary therapies.

As a first step breast cancer patients should be brought to change their lifestyle towards healthier habits for exercise, relaxation, and diet in order to improve quality of life already during conventional treatment. By doing this, it may be avoided that patients experiment with unproven therapies of questionable effectiveness.

\section{Limitations of the Survey}

There is a great variety of unconventional and unproven methods used by breast cancer patients. The list of therapies not belonging to conventional treatments is far too long as to be discussed correctly in this article. This review focused on treatments which are chosen by a great part of breast cancer patients and/or which might be helpful for symptom control based on an acceptable safety profile.

\section{References}

1 DiGianni LM, Garber JE, Winer EP: Complementary and alternative medicine use among women with breast cancer. J Clin Oncol 2002;20:34-38.

2 Molassiotis A, Scott JA, Kearney N, Pud D, Magri M, Selvekerova S, Bruyns I, Fernandez-Ortega P, Panteli V, Margulies A, Gudmundsdottir G, Milovics L, Ozeden G, Platin N, Patiraki E: Complementary and alternative medicine use in breast cancer patients in Europe. Support Care Cancer 2006;14:260-267.

3 Nahleh Z, Tabbara IA: Complementary and alternative medicine in breast cancer patients. Palliat Support Care 2003;1:267-273.

4 Downer SM, Cody MM, McCluskey P, Wilson PD Arnott SJ, Lister TA, Slevin ML: Pursuit and practice of complementary therapies by cancer patients receiving conventional treatment. BMJ 1994;309: 86-89.

5 Moschen R, Kemmler G, Schweigkofler H, Hozner B, Dunser M, Richter R, Fleischhacker WW Sperner-Unterweger B: Use of alternative/complementary therapy in breast cancer patients - a psychological perspective. Support Care Cancer 2001; 9:267-274.

6 Morris KT, Johnson N, Homer L, Walts D: A comparison of complementary therapy use between breast cancer patients and patients with other primary tumor sites. Am J Surg 2000;179:407-411.

7 Shumay DM, Maskarinec G, Gotay CC, Heiby EM, Kakai H: Determinants of the degree of complementary and alternative medicine use among patients with cancer. J Altern Complement Med 2002;8:661-671.
8 Cassileth BR, Deng G: Complementary and alternative therapies for cancer. Oncologist 2004;9:80-89.

9 Deng G, Cassileth BR, Yeung KS: Complementary therapies for cancer-related symptoms. J Support Oncol 2004;2:419-429.

10 Vickers AJ, Cassileth BR: Unconventional therapies for cancer and cancer-related symptoms. Lancet Oncol 2001;2:226-232.

11 Henderson JW, Donatelle RJ: Complementary and alternative medicine use by women after completion of allopathic treatment for breast cancer. Altern Ther Health Med 2004;10:52-57.

12 Markes M, Brockow T, Resch KL: Exercise for women receiving adjuvant therapy for breast cancer. Cochrane Database Syst Rev 2007, issue 2, DOI: 10.1002/14651858.CD005001.pub2.

13 Mutrie N, Campbell AM, Whyte F, McConnachie A, Emslie C, Lee L, Kearney N, Walker A, Ritchie D: Benefits of supervised group exercise programme for women being treated for early stage breast cancer: pragmatic randomised controlled trial. BMJ 2007;334:517-523.

14 Holmes MD, Chen WY, Feskanich D, Kroenke CH, Colditz GA: Physical activity and survival after breast cancer diagnosis. JAMA 2005;293:24792486.

15 Mock V, Atkinson A, Barsevick A, Cella D, Cimprich B, Cleeland C, Donnelly J, Eisenberger MA, Escalante C, Hinds P, Jacobsen PB, Kaldor P, Knight SJ, Peterman A, Piper BF, Rugo H, Sabbatini P, Stahl C: National Comprehensive Cancer Network oncology practice guidelines for cancerrelated fatigue. Oncology 2000;14:151-161.
16 Jereczek-Fossa BA, Marsiglia HR, Orecchia R: Radiotherapy-related fatigue: how to assess and how to treat the symptom - a commentary. Tumori 2001;87:147-151.

17 Feyer P, Steingraeber M: Fatigue - ein neues therapeutisches Problem in der Onkologie? [Fatigue - a new therapeutical problem in oncology?] Im Focus Onkologie 2001;7:59-64.

18 Vickers AJ, Straus DJ, Fearon B, Cassileth BR: Acupuncture for post-chemotherapy fatigue: a phase II study. J Clin Oncol 2004;22:1731-1735.

19 Laviano A, Meguid MM, Guijarro A, Muscaritoli M, Cascino A, Preziosa I, Molfino A, Fanelli FR: Antimyopathic effects of carnitine and nicotine. Curr Opin Clin Nutr Metab Care 2006;9:442-448.

20 McNeely ML, Campbell KL, Rowe BH, Klassen TP, Mackey JR, Courneya KS: Effects of exercise on breast cancer patients and survivors: a systematic review and meta analysis. CMAJ 2006;175: 34-41.

21 Williams AF, Vadgama A, Franks PJ, Mortimer PS: A randomized controlled crossover study of manual lymphatic drainage therapy in women with breast cancer-related lymphoedema. Eur J Cancer Care (Engl) 2002;11:254-261.

22 Ahles TA, Tope DM, Pinkson B, Walch S, Hann D, Whedon M, Dain B, Weiss JE, Mills L, Silberfarb PM: Massage therapy for patients undergoing autologous bone marrow transplantation. J Pain Symptom Manage 1999;18:157-163. 
23 Hernandez-Reif M, Field T, Ironson G, Beutler J, Vera Y, Hurley J, Fletcher MA, Schanberg S, Kuhn C, Fraser M: Natural killer cells and lymphocytes increase in women with breast cancer following massage therapy. Int J Neurosci 2005;115:495-510.

24 Prentice RL, Caan B, Chlebowski RT, Patterson R, Kuller LH, Ockene JK, Margolis KL, Limacher MC, Manson JE, Parker LM, Paskett E, Phillips L, Robbins J, Roussouw JE, Sarto GE, Shikany JM, Stefanick ML, Thomson CA, Van Horn L, Vitolins MZ, Wactawski-Wende J, Wallace RB, WassertheilSmoller S, Whitlock E, Yano K, Adams-Campbell L, Anderson GL, Assaf ÂR, Beresford SA, Black HR, Brunner RL, Brzyski RG, Ford L, Gass M, Hays J, Heber D, Heiss G, Hendrix SL, Hsia J, Hubbell FA, Jackson RD, Johnson KC, Kotchen JM, LaCroix AZ, Lane DS, Langer RD, Lasser NL, Henderson MM: Low fat dietary pattern and risk of invasive breast cancer: the Women's Health Initiative Randomized Controlled Dietary Modification Trial. JAMA 2006;295:629-642.

25 The American Cancer Society (ACS) Nutrition and Physical Activity Guidelines 2006: The Complete Guide - Nutrition and Physical Activity. http://caonline.amcancersoc.org/content/vol56/issue $5 /$.

26 Chlebowski RT, Blackburn GL Thomson CA, Nixon DW, Shapiro A, Hoy MK, Goodmann MT, Giuliano AE, Karanja N, McAndrew P, Hudis C, Butler J, Merkel D, Kristal A, Caan B, Michaelson R, Vinciguerra V, Del Prete S, Winkler M, Hall R, Simon M, Winters BL, Elashoff RM: Dietary fat reduction and breast cancer outcome: interim efficacy results from the Women's Intervention Nutrition Study. J Natl Cancer Inst 2006;98:1767-1776.

27 McMichael-Phillips DF, Harding C, Morton M, Roberts SA, Howell A, Potten CS, Bundred NJ: Effects of soy-protein supplementation on epithelial proliferation in the histologically normal human breast. Am J Clin Nutr 1998;68:1431S-1436S.

28 Messina M, McCaskill-Stevens W, Lampe JW: Addressing the soy and breast cancer relationship: review, commentary, and workshop proceedings. J Natl Cancer Inst 2006;98:1275-1284.

29 Boekhout AH, Beijnen JH, Schellens JHM: Symptoms and treatment in cancer therapy-induced early menopause. Oncologist 2006;11:641-654.

-30 Rosen T, deVeciana M, Miller HS, Stewart L, Rebarber A, Slotnick RN: A randomized controlled trial of nerve stimulation for relief of nausea and vomiting in pregnancy. Obstet Gynecol 2003; 102:129-135.

-31 Streitberger K, Diefenbacher M, Bauer A, Conradi R, Bardenheuer H, Martin E, Schneider A, Unnebrink K: Acupuncture compared to placebo acupuncture for postoperative nausea and vomiting prophylaxis: a randomized placebo controlled patient and observer blind trial. Anaesthesia 2004; 59:142-149.
32 Roscoe JA, Morrow GR, Hickock JT, Bushunow P, Pierce HI, Flynn PJ, Kirshner JJ, Moore DF, Atkins JN: The efficacy of acupressure and acustimulation wrist bands for the relief of chemotherapy-induced nausea and vomiting: a University of Rochester Cancer Center Community Clinical Oncology Program multicenter study. J Pain Symptom Manage 2003;26:731-742.

33 Alimi D, Rubino C, Pichard-Leandri E, FermandBrule S, Dubreuil-Lemaire ML, Hill C: Analgesic effect of auricular acupuncture for cancer pain: a randomized blinded controlled trial. J Clin Oncol 2003;21:4120-4126.

34 Escalante CP, Grover T, Johnson BA, Harle M, Guo H, Mendoza TR, Rivera E, Ho V, Lee EL, Cleeland CS: A fatigue clinic in a comprehensive cancer center: design and experiences. Cancer 2001;92:1708-1713.

35 Filshie J, Penn K, Ashley S, Davis CL: Acupuncture for the relief of cancer-related breathlessness. Palliat Med 1996;10:145-150.

36 Towlerton G, Filshie J, O'Brien M, Duncan A: Acupuncture in the control of vasomotor symptoms caused by tamoxifen. Palliat Med 1999;13:445.

\$37 Bjelakovic G, Nikolova D, Gluud LL, Simonetti RG, Gluud C: Mortality in randomized trials of antioxidant supplements for primary and secondary prevention: systematic review and meta-analysis. JAMA 2007;297:842-857.

38 Lajer H, Daugaard G: Cisplatin and hypomagnesemia. Cancer Treat Rev 1999;25:47-58

39 Pace A, Savarese A, Picardo M, Maresca V, Pacetti U, Del Monte G, Biroccio A, Leonetti C, Jandolo B, Cognetti F, Bove L: Neuroprotective effect of vitamin E supplementation in patients treated with cisplatin chemotherapy. J Clin Oncol 2003;21:927931

40 Barton DL, Loprinzi CL, Quella SK, Sloan JA, Veeder MH, Egner JR, Fidler P, Stella PJ, Swan DK, Vaught NL, Novotny P: Prospective evaluation of vitamin $\mathrm{E}$ for hot flashes in breast cancer survivors. J Clin Oncol 1998;16:495-500.

41 Thompson EA, Reilly D: The homeopathic approach to symptom control in the cancer patient: a prospective observational study. Palliat Med 2002;16:227-233.

42 Thompson EA, Montgomery A, Douglas D, Reilly D: A pilot, randomized, double-blinded, placebocontrolled trial of individualized homeopathy for symptoms of estrogen withdrawal in breast cancer survivors. J Altern Complement Med 2005;11: 13-20.

43 Carroll DG: Nonhormonal therapies for hot flashes in menopause. Am Fam Physician 2006;73:457-464.

44 Pommier P, Gomez F, Sunyach MP: Phase III randomized trial of Calendula officinalis compared with trolamine for the prevention of acute dermatitis during irradiation for breast cancer. J Clin Oncol 2004;22:1447-1453.

45 Dupuis LL, Nathan PC: Options for the prevention and management of acute chemotherapy-induced nausea and vomiting in children. Paediatr Drugs 2003;5:597-613.
46 Ernst E, Pittler MH: Efficacy of ginger for nausea and vomiting: a systematic review of randomized clinical trials. Br J Anaesth 2000;84:367-371.

47 Manusirivithaya S, Sripramote M, Tangjitgamol S, Sheanakul C, Leelahakorn S, Thavaramara T, Tangcharoenpanich K: Antiemetic effect of ginger in gynecologic oncology patients receiving cisplatin. Int J Gynecol Cancer 2004;14:1063-1069.

48 Attele AS, Wu JA, Yuan CS: Ginseng pharmacology: multiple constituents and multiple actions. Biochem Pharmacol 1999;58:1685-1693.

49 Kennedy DO, Scholey AB: Ginseng: potential for the enhancement of cognitive performance and mood. Pharmacol Biochem Behav 2003;75:687-700.

50 Cho J, Park W, Lee S, Ahn W, Lee Y: Ginsenoside$\mathrm{Rb} 1$ from Panax ginseng C.A. Meyer activates estrogen receptor-alpha and -beta, independent of ligand binding. J Clin Endocrinol Metab 2004;89: 3510-3515.

51 Cui Y, Shu XO, Gao YT, Cai H, Tao MH, Zheng W: Association of ginseng use with survival and quality of life among breast cancer patients. Am J Epidemiol 2006;163:645-653.

52 Fasching PA, Thiel F, Nicolaisen-Murmann K, Rauh C, Engel J, Lux MP, Beckmann MW, Bani MR: Association of complementary methods with quality of life and life satisfaction in patients with gynaecologic and breast malignancies. Support Care Cancer 2007; Epub ahead of print 17333294.

53 Grossarth-Maticek R, Ziegler R: Randomised and non-randomised prospective controlled cohort studies in matched pair design for the long-term therapy of breast cancer patients with a mistletoe preparation: a re-analysis. Eur J Med Res 2006;11: 485-495.

54 Gabius HJ, Darro F, Remmelink M, Andre S, Kopitz J, Danqui A, Gabius S, Salmon I, Kiss R Evidence for stimulation of tumor proliferation in cell lines and histiotypic cultures by clinically relevant low doses of the galactoside-binding mistletoe lectin, a component of proprietary extracts. Cancer Invest 2001;19:114-126.

55 Maier G, Fiebig HH: Absence of tumor growth stimulation in a panel of 16 human tumor cell lines by mistletoe extract in vitro. Anticancer Drugs 2002;13:373-379.

56 Büssing A: Mistel (Viscum album); in Münstedt K (ed): Ratgeber unkonventionelle Krebstherapien. Landsberg/Lech, ecomed, 2003, pp 184-199.

57 Zhang M, Liu X, Li J, He L, Tripathy D: Chinese medicinal herbs to treat the side-effects of chemotherapy in breast cancer patients. Cochrane Database Syst Rev 2007, issue 2, DOI: 10.1002/ 14651858.CD004921.pub2.

58 Lee TI, Chen HH, Yeh ML: Effects of chan-chuang qigong on improving symptom and psychological distress in chemotherapy patients. Am J Chin Med 2006;34:37-46.

59 Devine EC, Westlake SK: The effects of psychoeducational care provided to adults with cancer: meta analysis of 116 studies. Oncol Nurs Forum 1995;22: 1369-1381. 